\title{
Complement activation mediates cetuximab inhibition of non-small cell lung cancer tumor growth in vivo
}

\author{
Yi-Fan Hsu'1, Daniel Ajona1', Leticia Corrales¹, Jose M Lopez-Picazo², Alfonso Gurpide², Luis M Montuenga1,3 and \\ Ruben Pio*1,4
}

\begin{abstract}
Background: Cetuximab, an antibody targeting the epidermal growth factor receptor (EGFR), increases survival in patients with advanced EGFR-positive non-small cell lung cancer when administrated in combination with chemotherapy. In this study, we investigated the role of complement activation in the antitumor mechanism of this therapeutic drug.

Results: EGFR-expressing lung cancer cell lines were able to bind cetuximab and initiate complement activation by the classical pathway, irrespective of the mutational status of EGFR. This activation led to deposition of complement components and increase in complement-mediated cell death. The influence of complement activation on the activity of cetuximab in vivo was evaluated in xenografts of A549 lung cancer cells on nude mice. A549 cells express wild-type EGFR and have a KRAS mutation. Cetuximab activity against A549 xenografts was highly dependent on complement activation, since complement depletion completely abrogated the antitumor efficacy of cetuximab. Moreover, cetuximab activity was significantly higher on $\mathrm{A} 549$ cells in which a complement inhibitor, factor $\mathrm{H}$, was genetically downregulated.

Conclusions: We demonstrate for the first time that the in vivo antitumor activity of cetuximab can be associated with a complement-mediated immune response. These results may have important implications for the development of new cetuximab-based therapeutic strategies and for the identification of markers that predict clinical response.
\end{abstract}

\section{Background}

Lung cancer accounts for more than $25 \%$ of all cancer deaths in United States [1]. Non-small cell lung cancer (NSCLC) represents about $80 \%$ of all lung cancers. Current treatment options consist of surgical resection, platinum-based doublet chemotherapy, and radiation. Unfortunately, despite these therapies, the prognosis remains poor. Recent advances in the understanding of the molecular pathogenesis of the disease have led to the development of molecular targeted therapies for NSCLC [2]. Bevacizumab, a monoclonal antibody to vascular endothelial growth factor, and erlotinib, a small-molecule tyrosine kinase inhibitor (TKI) of epidermal growth factor receptor (EGFR), are targeted agents approved in the

\footnotetext{
* Correspondence: rpio@unav.es

1 Division of Oncology, Center for Applied Medical Research (CIMA), Pamplona, Spain

Full list of author information is available at the end of the article
}

treatment of NSCLC [3]. The clinical efficacy of cetuximab, a humanized monoclonal antibody against the extracellular domain of EGFR, has also been evaluated. A randomized phase III trial has recently shown significantly prolonged survival of advanced NSCLC patients who received cetuximab in combination with platinumbased chemotherapy as first-line treatment [4]. Conversely, combinations of gefitinib or erlotinib, EGFR tyrosine kinase inhibitors (TKIs), with standard chemotherapy in advanced NSCLC have failed to show clinical benefit [5-8]. Another remarkable observation is that, in contrast to the evidence for TKI treatment, KRAS mutation status does not appear to be predictive of response to cetuximab in NSCLC [9-11]. These data strongly suggest clinically relevant differences between the mechanisms of action of EGFR-TKIs and cetuximab [12]. In this sense, it has been suggested that immune mechanisms may con- 
tribute to the antitumor activity of cetuximab [13]. In particular, cetuximab, alone or in combination with other antibodies, may elicit immunological responses such as antibody-dependent cellular cytotoxicity (ADCC) or complement activation [14-17].

A better understanding of the mechanisms that govern cetuximab antitumor activity is necessary to optimize its therapeutic efficacy and to identify those patients who are going to benefit from the treatment. In the current report we investigated the influence of the activation of complement in the action of cetuximab in an in vivo animal model. We also explored the possibility of enhancing complement activation in an attempt to increase the clinical efficacy of cetuximab.

\section{Methods}

\section{Lung cancer cell lines}

A549 (lung adenocarcinoma), HCC827 (lung adenocarcinoma), and H187 (small-cell lung carcinoma) cell lines were obtained from the American Type Culture Collection. Cells were grown in RPMI 1640 supplemented with 10\% Fetalclone III (Hyclone), $100 \mathrm{U} / \mathrm{ml}$ penicillin, and $100 \mu \mathrm{g} / \mathrm{ml}$ streptomycin.

\section{Sera}

Normal human serum (NHS) was used as the source of complement. A pool of sera from ten healthy donors was prepared. Heat inactivated NHS (HI-NHS) was obtained by incubation of the serum at $56^{\circ} \mathrm{C}$ for 30 minutes.

\section{EGFR mRNA expression}

RNA was purified from cells using the Ultraspec Total RNA Isolation Reagent (Biotecx). RNA was reverse transcribed and the expression of human EGFR mRNA was analyzed by PCR using the following primers: sense 5'GGACGACGTGGTGGATGCCG-3', antisense 5'GGCGCCTGTGGGGTCTGAGC-3'. GAPDH was used as an internal control. Primers for GAPDH mRNA amplification were: sense 5'-ACTTTGTCAAGCTCATTTCC3', antisense 5'-CACAGGGTACTTTATTGATG-3'. PCR conditions were: 1 cycle of $2 \mathrm{~min}$ at $95^{\circ} \mathrm{C}$, followed by 30 cycles of $30 \mathrm{sec}$ at $95^{\circ} \mathrm{C}, 30 \mathrm{sec}$ at $55^{\circ} \mathrm{C}$, and $30 \mathrm{sec}$ at $72^{\circ} \mathrm{C}$, and finishing with $10 \mathrm{~min}$ at $72^{\circ} \mathrm{C}$.

\section{KRAS mutations}

Human KRAS codon 12 mutations were assessed by sequencing. Genomic DNA was subjected to PCR amplification with the following set of intronic primers: sense 5'-CGATACACGTCTGCAGTCAA-3', antisense 5'GGTCCTGCACCAGTAATATGC-3'. The PCR products were sequenced using the Big Dye Terminator V1.1 Cycle Sequencing Kit (Applied Biosystems) according to the protocol supplied by the manufacturer.

\section{C1q fixation}

A polystyrene 96-well plate was coated with 30 to $2000 \mathrm{ng}$ of antibody per well in $100 \mu \mathrm{l}$ of $50 \mathrm{mM}$ sodium bicarbonate ( $\mathrm{pH} 8.3)$ during one hour at room temperature. After washing, the plate was blocked overnight at $4^{\circ} \mathrm{C}$ with Tris-buffered saline (TBS) containing 1\% bovine serum albumin, and $0.1 \%$ Tween 20. After washing, normal human serum, used as the source of C1q, was added in $100 \mu \mathrm{l}$ of veronal buffer [1.8 mM barbital, $3.1 \mathrm{mM}$ barbituric acid, $141 \mathrm{mM}$ sodium chloride, $0.5 \mathrm{mM} \mathrm{MgCl}_{2}$ and $0.15 \mathrm{mM} \mathrm{CaCl}_{2}$ (pH 7.4)] and incubated for $30 \mathrm{~min}$ at $37^{\circ} \mathrm{C}$. The plate was washed and the assay was developed with a rabbit anti-human C1q antibody (1:500; Dako), a goat anti-rabbit antibody coupled to horseradish peroxidase (1:1,000; Sigma-Aldrich) and O-phenylenediamine dihydrochloride (Sigma-Aldrich). A human IgG1 antibody (Sigma-Aldrich) was used as a positive control. The anti-factor $\mathrm{H}$ monoclonal antibody $\mathrm{OX} 24$, and heat inactivated NHS $\left(56^{\circ} \mathrm{C}\right.$ for 30 minutes) were used as negative controls. Cetuximab was kindly provided by Merck KGaA. OX24 was obtained as previously described [18].

\section{Binding of cetuximab and deposition of complement components}

Cells were detached from culture dishes with trypsin/ EDTA (Lonza), washed once, and resuspended in veronal buffer. Cells $\left(2 \times 10^{5}\right)$ were mixed and incubated for 15 min at $37^{\circ} \mathrm{C}$ with NHS (diluted 1:5) and cetuximab (40 $\mu \mathrm{g} / \mathrm{ml}$ ). After washing, cells were incubated for $30 \mathrm{~min}$ at $4^{\circ} \mathrm{C}$ with the following antibodies: fluorescein isothiocyanate (FITC)-conjugated goat anti-human IgG (1:100; Sigma-Aldrich), rabbit anti-human C1q (1:100; Dako), FITC-conjugated goat anti-human C3 (1:100, ICN Biomedicals), or mouse anti-human C5b-9 (1:100; Dako). Secondary antibodies were goat anti-rabbit IgG labeled with Alexa-Fluor 488 (1:100; Invitrogen), or FITC-conjugated goat anti-mouse IgG (1:100; Invitrogen). Cells were analyzed by flow cytometry.

\section{Complement-mediated cell death}

Complement-mediated cell death is associated with DNA fragmentation [19]. DNA fragmentation was evaluated using a method previously described [20]. In brief, $7 \times 10^{5}$ cells were resuspended in $0.2 \mathrm{ml}$ of RPMI medium containing 30\% NHS (or HI-NHS), and treated with $40 \mu \mathrm{g} / \mathrm{ml}$ of cetuximab for 24 hours at $37^{\circ} \mathrm{C}$. Afterwards, cells were pelleted and fixed in $2 \mathrm{ml}$ of cold $70 \%$ ethanol for $60 \mathrm{~min}$ at $4^{\circ} \mathrm{C}$. Cells were centrifuged, washed twice with PBS, resuspended in $0.5 \mathrm{ml}$ of PBS, and incubated with $10 \mu \mathrm{l}$ of $1 \mathrm{mg} / \mathrm{ml} \mathrm{RNase}$ A (Sigma) during 1 hour at $37^{\circ} \mathrm{C}$. Finally, $5 \mu \mathrm{l}$ of $1 \mathrm{mg} / \mathrm{ml} 7$-aminoactinomycin D (Sigma) were added and, after incubation in the dark for $15 \mathrm{~min}$ at room temperature, cells were analyzed by flow cytome- 
try. The percentage of DNA giving fluorescence below the $G_{1} / G_{0}$ peak was taken as measure of cell death.

\section{Cell proliferation assay}

Cells (2,000 A459 cells/well or 4,000 HCC827 cells/well) were seeded in 96-well plates in RPMI medium supplemented with $10 \%$ FBS. Twenty-four hours later, cells were treated with cetuximab at different concentrations, and incubated for another 24 hours. Ten microliters of MTT (3-(4,5-dimethylthiazol-2-yl)-2,5-diphenyltetrazolium bromide) at $5 \mathrm{~g} / \mathrm{l}$ (Sigma) was added to each well and incubated for 4 hours at $37^{\circ} \mathrm{C}$. Later, $100 \mu \mathrm{l}$ of dimethyl sulfoxide was added to each well to dissolve the MTT-formazan crystals. Absorbance was measured at $540 \mathrm{~nm}$, with a reference filter at $690 \mathrm{~nm}$, using a microplate reader.

\section{Xenograft model}

Care of the animals was in accord with our institution guidelines. A549 cells $\left(15 \times 10^{6}\right)$ were mixed 1:1 with Growth Factor Reduced Matrigel Matrix (BD Biosciences), and injected subcutaneously on the right flank of 4-6 week old female athymic nude mice (Harlan Laboratories, Italy). Athymic mice are immunodeficient and cannot develop a complete adaptive immune response, but have complement and NK cell activities. Tumor growth was measured every 2-3 days. Tumor volume was calculated using the formula: Volume $=$ length $\times$ width $^{2} \times$ 0.5 . Tumors were allowed to reach about $200-250 \mathrm{~mm}^{3}$ before randomization. When indicated, complement was depleted with cobra venom factor (CVF), as previously described [21].

\section{C3 immunofluorescence}

Xenografts were harvested, fixed in buffered formalin, paraffin-embedded and sectioned ( $5 \mu \mathrm{m}$ thick). Slides were deparaffinized, blocked with normal rabbit serum (1:20 dilution), and incubated with a goat anti-mouse C3 (1:500; Santa Cruz Biotechnology). Afterwards, slides were washed and incubated with a rabbit anti-goat IgG coupled to Alexa-Fluor 488 (1:500; Invitrogen). Slides were washed, mounted, and analyzed in an Olympus fluorescence microscope.

\section{Statistical analysis}

Data were analyzed by Student's t-test. A p value of less than 0.05 was considered as statistically significant.

\section{Results and Discussion}

We used three different lung cancer cell lines in the study: A549, HCC827, and H187 cells. A549 cells express wildtype EGFR and have a KRAS mutation (Fig. 1A-B). HCC827 cells express mutated-EGFR and wild-type KRAS. H187 cells do not have detectable levels of EGFR. We first analyzed the capacity of cetuximab to fix com-

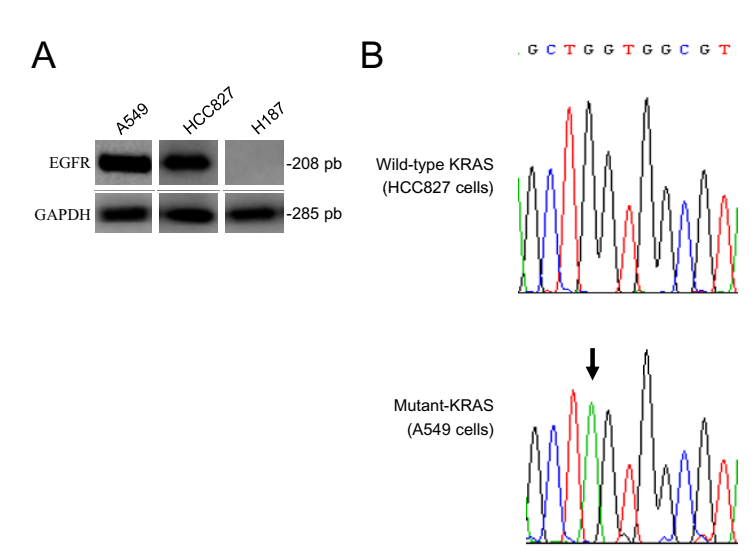

Figure 1 Characterization of the lung cancer cell lines used in the study. A, Expression of EGFR mRNA in A549, HCC827 and H187 cells determined by RT-PCR. GAPDH was used as a control. B, Confirmation of a KRAS codon 12 mutation (GGT > AGT) in A549 cells.

plement. C1q from NHS was able to bind to wells coated with cetuximab (Fig. 2A), but not to wells coated with OX24, an IgG1 monoclonal antibody unable to fix complement [18]. C1q binding to cetuximab was inhibited by heat inactivation. We next assessed the capacity of cetuximab to fix complement on the membrane of lung cancer cells. We used $40 \mu \mathrm{g} / \mathrm{ml}$ of cetuximab (at the FDAapproved dosing level, according to the manufacturer, the peak and trough plasma concentrations of cetuximab range from 168 to $235 \mu \mathrm{g} / \mathrm{ml}$ and from 41 to $85 \mu \mathrm{g} / \mathrm{ml}$, respectively). In cells expressing EGFR, cetuximab treatment initiated complement activation, irrespective of the mutational status of EGFR (Fig. 2B-C). Complement activation by the antibody-dependent classical pathway results in C3b-deposition, which leads to the formation of the cytolytic C5b-C9 complex [22]. Treatment of EGFRexpressing cells with cetuximab and NHS led to the deposition of these complement components and to complement-mediated cell death (Fig. 3A-B). In contrast, Kimura et al previously reported that complement dependent cytotoxicity was not detected in A549 cells treated with cetuximab [14], and Dechant et al found that complement activation only occurred when cetuximab was combined with other EGFR antibodies [17]. In both studies cetuximab was used at $10 \mu \mathrm{g} / \mathrm{ml}$. We confirmed that there is not complement-mediated cell death with 10 $\mu \mathrm{g} / \mathrm{ml}$ of cetuximab, but higher concentrations are required (data not shown). As mentioned above, the concentration used in the present study $(40 \mu \mathrm{g} / \mathrm{ml})$ is similar to the lowest concentration found in plasma from patients treated with the standard dosing of cetuximab. Treatment of EGFR-negative H187 cells with $40 \mu \mathrm{g} / \mathrm{ml}$ of cetuximab did not affect C3b-deposition, C5b-C9 complex formation, or complement-mediated cell death (Fig. 


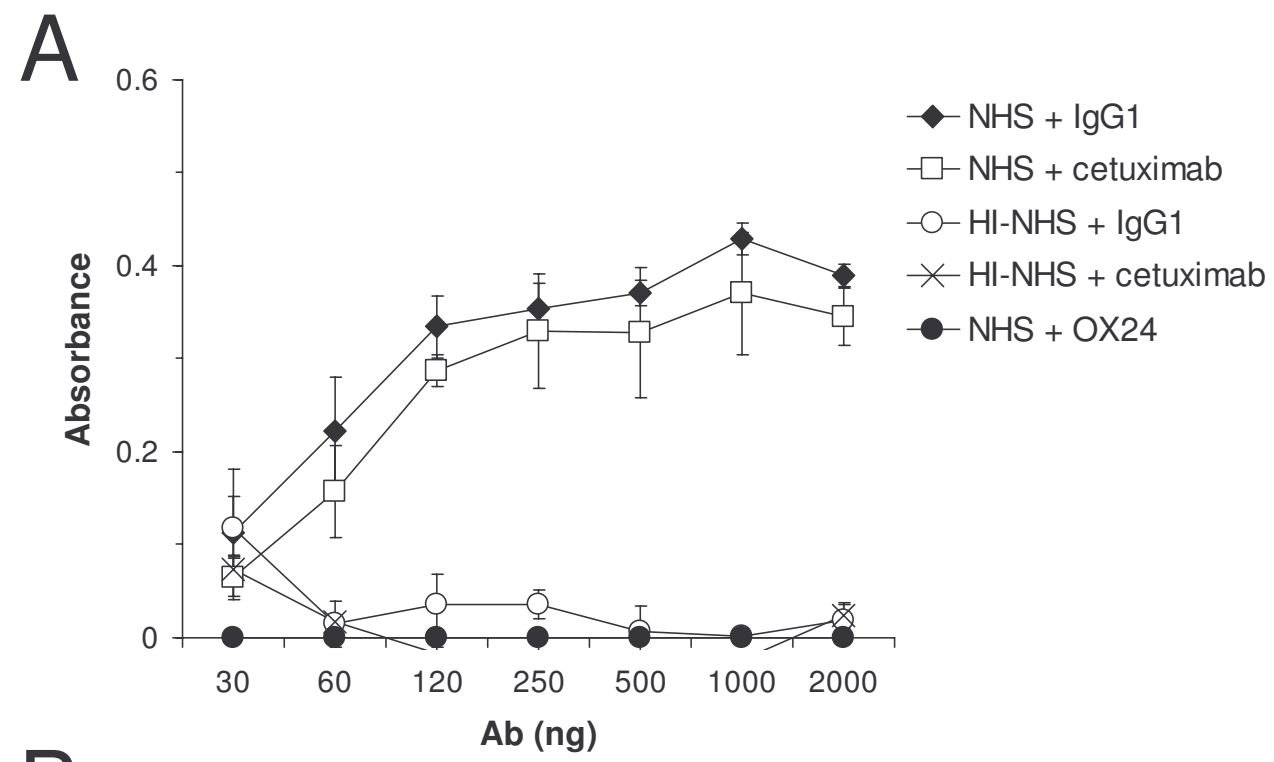

B
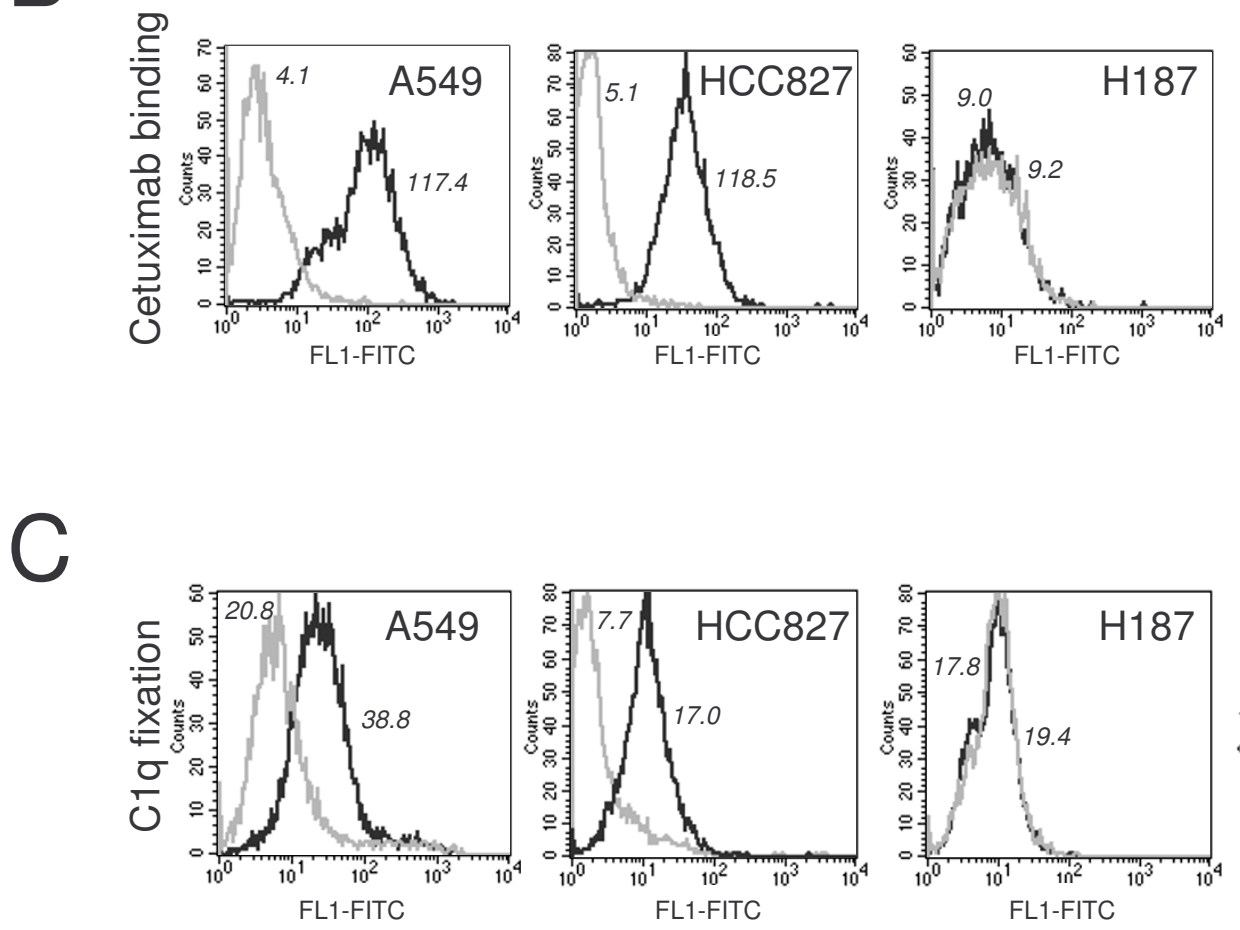

Figure 2 Complement fixation by cetuximab. A, C1q binding to cetuximab was first evaluated in wells coated with different amounts of antibody and incubated with 1\% NHS. A human IgG1 antibody able to fix C1q was used as a positive control. Monoclonal antibody OX24 and heat inactivated NHS (HI-NHS) were used as negative controls. Data shows mean \pm SEM. B, Flow cytometry analysis of the binding of cetuximab to lung cancer cells (black line). A human IgG1 was used as an isotype control (grey line). C, Lung cancer cells were incubated with NHS and cetuximab. The binding of C1q to the Fc-region of cetuximab was analyzed by flow cytometry with the anti-human C1q antibody (black line) or an isotype control (grey line). Mean fluorescence intensities (MFI) are indicated. 


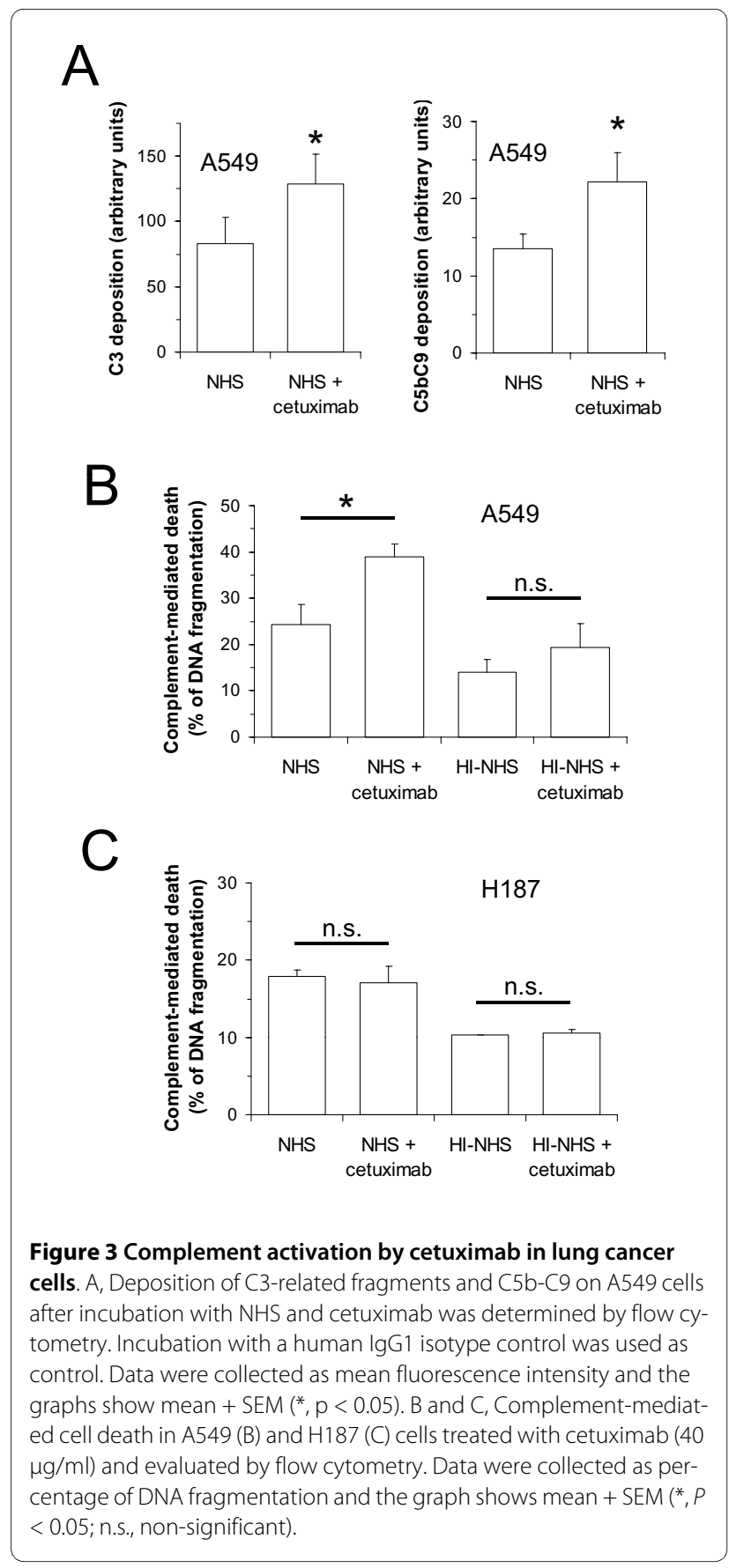

3C). These results suggest that, upon binding of cetuximab to the cell membrane of EGFR-positive cells, the classical pathway of complement is initiated.

It is important to realize that lysis is not the only biological consequence of complement activation in vivo. For example, complement activation releases anaphylatoxins that promote proinflammatory responses. In addition, the interaction of $\mathrm{iC} 3 \mathrm{~b}$ with CR3 (CD11b/CD18) on immune cells mediates complement-dependent cellular cytotoxicity (CDCC). Therefore, cetuximab-mediated complement activation may generate a powerful antitumor response in an in vivo setting. To test this hypothesis, we used A549 cells, which express wild-type EGFR and have a KRAS mutation. In in vitro studies, A549 cells are insensitive to the blockade of EGFR signaling and resistant to cetuximab [23]. This resistance may be a consequence of the presence of the KRAS mutation. However, cetuximab has some antitumor effect in vivo in A549 xenografts grown in nude mice [24]. This observation strongly suggests that cetuximab operates by in vivo mechanisms of action other than inhibition of EGFR-signaling. We first confirmed the resistance of A549 cells to cetuximab using an MTT assay (Fig 4A). Afterwards, we grew A549 xenografts in athymic mice and treated them with cetuximab. As previously reported [24], tumor growth was partially inhibited by cetuximab (Fig. 4B). Interestingly, explanted tumors from mice treated with cetuximab had high levels of $\mathrm{C} 3$ deposition, demonstrat-
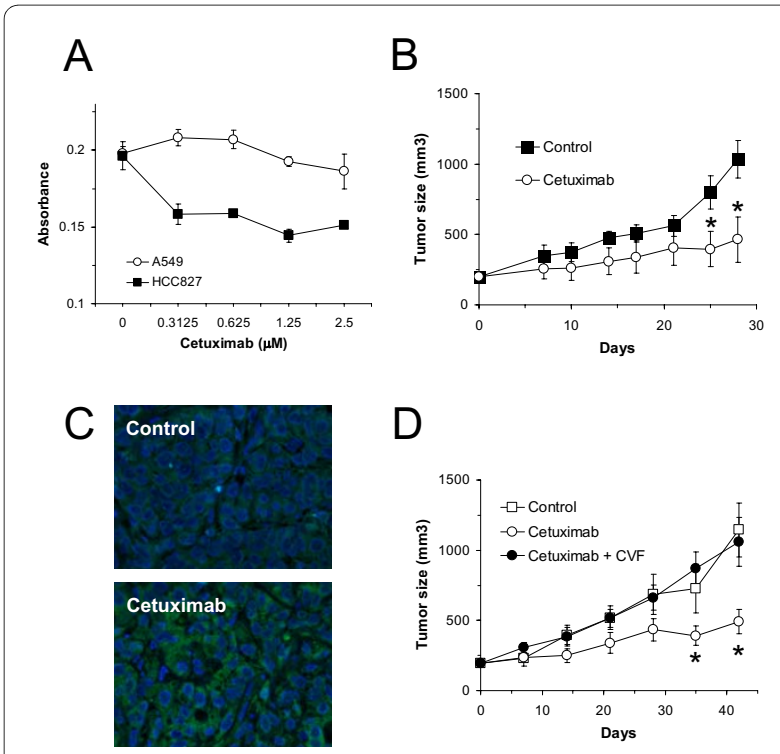

Figure 4 Complement-dependent antitumor activity of cetuximab in A549 xenografts. A, MTT assay for the in vitro antitumor activity of cetuximab in A549 and HCC827 lung cancer cell lines (with wildtype and mutant-EGFR, respectively). Cell proliferation was determined after $24 \mathrm{~h}$ treatment using an MTT assay. The graph shows mean \pm SEM. B, A549 cells were injected s.c. on athymic nude mice. When tumors reached $200-250 \mathrm{~mm}^{3}$, mice $(n=10)$ were randomized into two groups: one was treated with cetuximab and the other with PBS. Cetuximab was administered i.p. at $0.5 \mathrm{mg}$ per mouse three times a week and tumor growth was measured every 2-3 days. Data represent mean \pm SEM ( $\left.{ }^{*}, P<0.05\right)$. C, Representative example of the deposition of C3-related fragments, determined by immunofluorescence, in explanted tumors from each experimental group. D, A549 xenografts were generated as above. Animals $(n=18)$ were divided into three groups. In one group, complement was depleted with CVF. Cetuximab treatment was administrated to the CVF-treated group and to a second group with full complement activity. The last group received PBS. Data represent mean \pm SEM $(*, P<0.05)$. 
ing the capacity of cetuximab to activate complement in vivo (Fig. 4C). The contribution of complement in the reduction of tumor growth was confirmed using complement-deficient mice. Complement depletion was achieved with cobra venom factor (CVF). Serum C3 levels were reduced to less than $10 \%$ as evaluated by ELISA (data not shown). Complement depletion completely abrogated the activity of cetuximab in A549 xenografts (Fig. 4D).

The efficacy of complement-activating antibodies could be potentiated by the induction of immune effectors suppressed by the tumor microenvironment. In this line, we tried to increase the efficacy of cetuximab by eliminating the control exerted by factor $\mathrm{H}$, a complement inhibitor that prevents an efficient immune response against lung cancer cells [21]. Incubation of A549 cells with NHS and cetuximab in the presence of OX24 significantly increased the deposition of C3-related fragments (Fig. $5 \mathrm{~A})$. OX24 is an antibody that inhibits the binding of factor $\mathrm{H}$ to surface-bound $\mathrm{C} 3 \mathrm{~b}$. To evaluate the contribution of factor $\mathrm{H}$ to the control of complement-mediated cetuximab activity, we used A549 cells in which the expression of factor $\mathrm{H}$ was stably downregulated by siRNA [21]. The antitumor activity of cetuximab was significantly higher in factor H-deficient cells than in cells transfected with a control siRNA (Fig. 5B). Cetuximab-mediated tumor growth reduction was more than $90 \%$ in factor $\mathrm{H}$-deficient cells, compared to around $50 \%$ in control cells. In vivo antitumor activity of cetuximab was again associated with an increase in the deposition of C3-related fragments (Fig. 5C). In conclusion, these results demonstrate for the first time that a complement-mediated immune response induced by cetuximab participates in the control of tumor cell growth in vivo. This mechanism of action provides numerous opportunities to enhance the efficacy of therapeutical monoclonal antibodies [25].

Human tumors in immunocompromised mouse models do not entirely behave as syngeneic tumors in immunocompetent hosts. For example, although athymic mice have normal complement activity, they cannot develop an adequate adaptive immune response. In an intact immune system, both ADCC and CDCC would likely be important mediators of cetuximab antitumor activity (Fig. 6). Thus, the efficacy of cetuximab against human tumors might be attenuated in our immunocompromised animal model. Still, our data clearly indicate that complement activation is sufficient to elicit an intense response able to induce more than $90 \%$-reduction in the tumor growth of cells resistant to blockade of the EGFR-signaling pathway. It would be also possible that the activation of complement may contribute to the antitumor effect of cetuximab in cells sensitive to the blockade of this pathway.

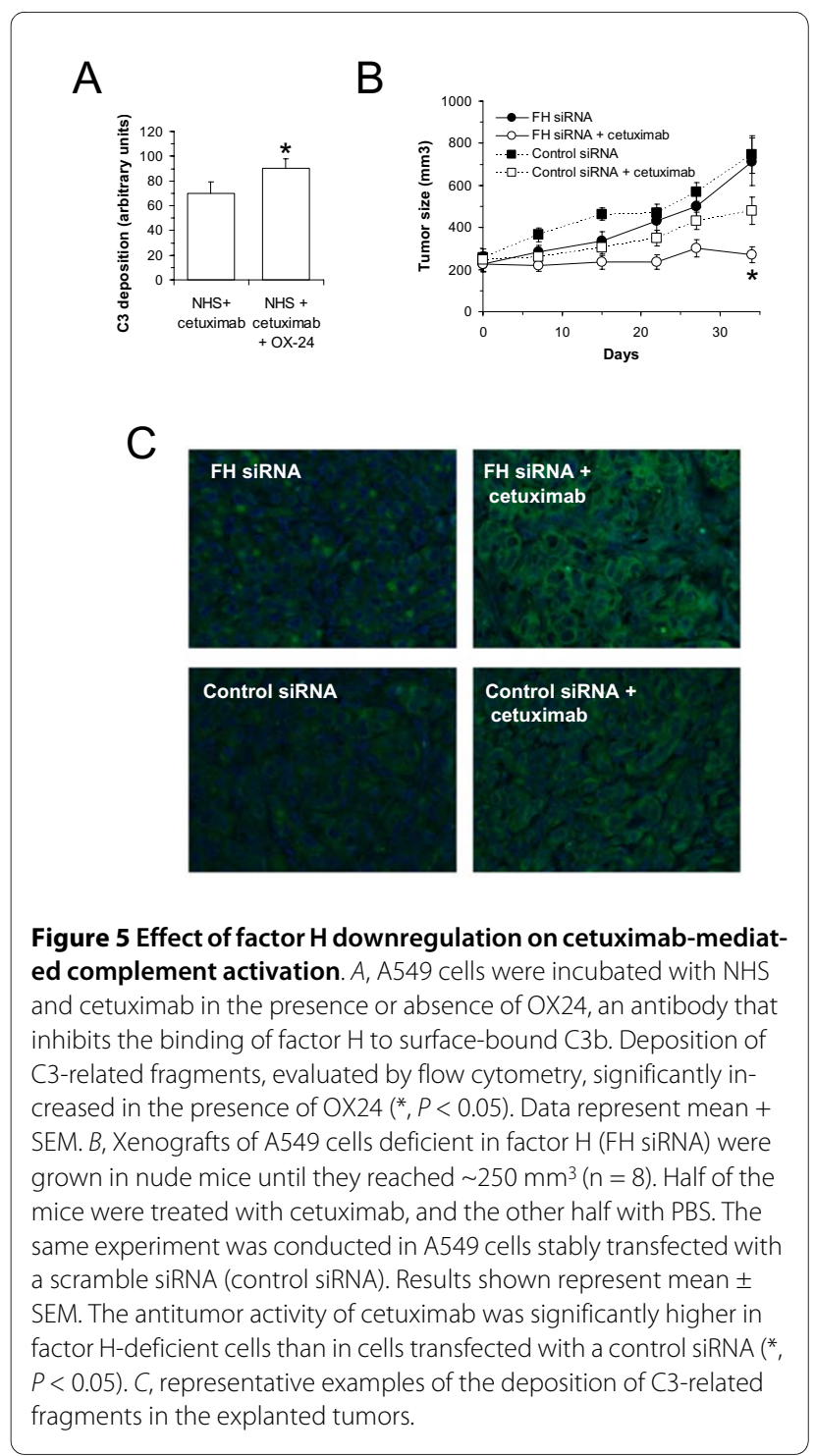

It would be interesting to evaluate the immune mechanisms through which complement activation is able to control tumor growth. A direct effect of complement on the target cells may be accompanied by the recruitment and activation of cellular effectors such as lymphokine activated killer (LAK) cells and natural killer (NK) cells. In addition, the combination of cetuximab with modifiers of the immune response may be considered an attractive therapeutic approach to enhance the clinical efficacy of cetuximab against lung, colorectal, and head and neck carcinomas. For example, clinical trials are underway using cetuximab in combination with $\beta$-glucans to treat colorectal cancer. $\beta$-glucans are polysaccharides that collaborate with complement-activating antibodies in the elimination of tumors [26]. Cetuximab may also be combined with other monoclonal antibodies to potentiate complement activation [17]. Modifications in the Fcregion of the monoclonal antibody can also be attempted 


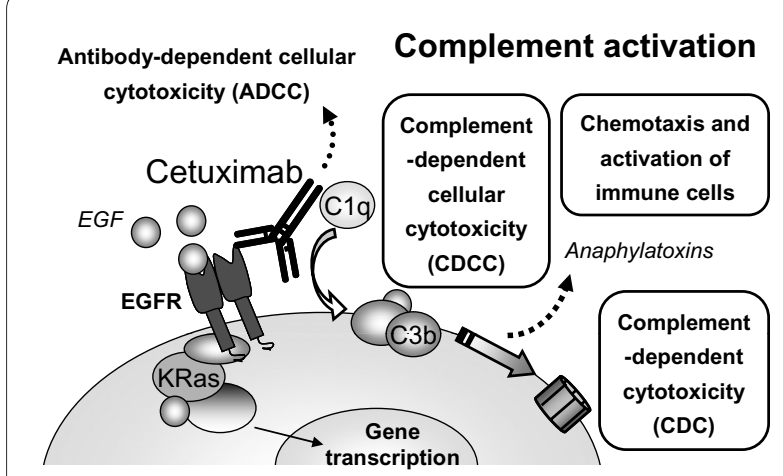

Figure 6 Effector mechanisms triggered by cetuximab. Cetuximab can inhibit EGFR-intracellular signaling or induce an immune response. These two antitumor mechanisms may act in conjunction. In certain conditions, such as in the presence of KRAS mutations, the immune response may be particularly important. The activation of the immune system by cetuximab can lead to both antibody-dependent cellular cytotoxicity (ADCC) and complement activation. Complement activation results in complement-dependent cellular cytotoxicity (CDCC) and/or complement-dependent cytotoxicity (CDC). CDCC is mediated by the interaction of C $3 \mathrm{~b}$ and its receptors in effector cells (e.i. phagocytes and NK cells). The release of anaphylatoxins, such as C5a, would further increase the recruitment and activation of effector cells. The three main immune consequences of complement activation are summarized in the boxes.

to increase the ability of the antibody's activation of complement [27].

In an unselected population, cetuximab treatment, as many other biological agents, only benefits a small percentage of NSCLC patients [28]. The body of knowledge that has paved the way for more targeted use of cetuximab has been recently reviewed [29]. Many groups are also focusing their research on markers of response (or resistance) to cetuximab. A more rational use of EGFRtargeted agents, such as cetuximab, should provide benefits for patients and health-care providers alike by sparing patients unnecessary treatment and allowing better use of health-care resources [29]. However, at present, no molecular biomarker is available to predict response to cetuximab in NSCLC. Based on our results, polymorphisms or other genetic traits that modulate the immune function may condition the activity of cetuximab, serving as markers to predict clinical response.

\section{Conclusions}

There is a pressing need to elucidate the molecular mechanisms involved in cetuximab activity in order to improve its clinical efficacy and to better select patients who would benefit from cetuximab treatment. In this paper we demonstrate that a complement-mediated immune response participates in the inhibition of tumor cell growth by cetuximab in vivo. This observation may have important clinical implications in the development of new cetuximab-based therapeutic strategies and in the identification of markers that predict clinical response.

\section{Competing interests}

The authors declare that they have no competing interests.

\section{Authors' contributions}

JMLP, AG, LMM and RP conceived the study. YFH, LMM and RP were responsible for the experimental design. YFH, DA and LC performed experiments and helped in the analysis and interpretation. YFH, JMLP, AG, LMM and RP prepared the manuscript. All authors read and approved the final version of the manuscript.

\section{Acknowledgements}

This work was supported by UTE project CIMA, Spanish Ministry of Science and Innovation [SAF2005-01302], Spanish Ministry of Health [FIS-PI080923], Red Temática de Investigación Cooperativa en Cáncer [RTICC, RD06/0020/0066], Instituto de Salud Carlos III (ISCIII), Spanish Ministry of Science and Innovation \& European Regional Development Fund (ERDF) "Una manera de hacer Europa". Cetuximab was kindly provided by Merck KGaA.

\section{Author Details}

1Division of Oncology, Center for Applied Medical Research (CIMA), Pamplona, Spain, 2Department of Oncology, Clinica Universidad de Navarra, Pamplona, Spain, ${ }^{3}$ Department of Histology, School of Medicine. University of Navarra, Pamplona, Spain and ${ }^{4}$ Department of Biochemistry, School of Sciences. University of Navarra, Pamplona, Spain

Received: 15 January 2010 Accepted: 7 June 2010

Published: 7 June 2010

\section{References}

1. Jemal A, Siegel R, Ward E, Hao Y, Xu J, Thun MJ: Cancer Statistics, 2009. CA Cancer J Clin 2009, 59:225-249.

2. Sun S, Schiller JH, Spinola M, Minna JD: New molecularly targeted therapies for lung cancer. J Clin Invest 2007, 117:2740-2750.

3. Dubey S, Powell CA: Update in lung cancer 2008. Am J Respir Crit Care Med 2009, 179:860-868.

4. Pirker R, Pereira JR, Szczesna A, von Pawel J, Krzakowski M, Ramlau R, Vynnychenko I, Park K, Yu CT, Ganul V, Roh JK, Bajetta E, O'Byrne K, de Marinis F, Eberhardt W, Goddemeier T, Emig M, Gatzemeier U, FLEX Study Team: Cetuximab plus chemotherapy in patients with advanced nonsmall-cell lung cancer (FLEX): an open-label randomised phase III trial. Lancet 2009, 373:1525-1531.

5. Giaccone G, Herbst RS, Manegold C, Scagliotti G, Rosell R, Miller V, Natale RB, Schiller JH, Von Pawel J, Pluzanska A, Gatzemeier U, Grous J, Ochs JS, Averbuch SD, Wolf MK, Rennie P, Fandi A, Johnson DH: Gefitinib in combination with gemcitabine and cisplatin in advanced non-smallcell lung cancer: a phase III trial--INTACT 1. J Clin Oncol 2004, 22:777-784

6. Herbst RS, Giaccone G, Schiller JH, Natale RB, Miller V, Manegold C, Scagliotti G, Rosell R, Oliff I, Reeves JA, Wolf MK, Krebs AD, Averbuch SD, Ochs JS, Grous J, Fandi A, Johnson DH: Gefitinib in combination with paclitaxel and carboplatin in advanced non-small-cell lung cancer: a phase III trial--INTACT 2. J Clin Oncol 2004, 22:785-794.

7. Herbst RS, Prager D, Hermann R, Fehrenbacher L, Johnson BE, Sandler A, Kris MG, Tran HT, Klein P, Li X, Ramies D, Johnson DH, Miller VA, TRIBUTE Investigator Group: TRIBUTE: a phase III trial of erlotinib hydrochloride (OSI-774) combined with carboplatin and paclitaxel chemotherapy in advanced non-small-cell lung cancer. J Clin Oncol 2005, 23:5892-5899.

8. Gatzemeier U, Pluzanska A, Szczesna A, Kaukel E, Roubec J, De Rosa F, Milanowski J, Karnicka-Mlodkowski H, Pesek M, Serwatowski P, Ramlau R, Janaskova T, Vansteenkiste J, Strausz J, Manikhas GM, Von Pawel J: Phase III study of erlotinib in combination with cisplatin and gemcitabine in advanced non-small-cell lung cancer: the Tarceva Lung Cancer Investigation Trial. J Clin Oncol 2007, 25:1545-1552.

9. Khambata-Ford S, Harbison C, Woytowitz D, Awad M, Horak C, Xu LA, Dakhil S, Hermann RC, Lynch TJ, Weber MR: K-Ras mutation (mut), EGFRrelated, and exploratory markers as response predictors of cetuximab in first-line advanced NSCLC: Retrospective analyses of the BMS099 trial. Journal of Thoracic Oncology 2009, 27:15s. (suppl; abstr 8021) 
10. Mack PC, Holland WS, Redman M, Lara PN, Snyder LJ, Hirsch FR, Franklin WA, Kim ES, Herbst RS, Gandara DR: KRAS mutation analysis in cetuximab-treated advanced stage non-small cell lung cancer (NSCLC): SWOG experience with S0342 and S0536. Journal of Thoracic Oncology 2009, 27:15s. (suppl; abstr 8022)

11. O'Byrne KJ, Bondarenko I, Barrios C, Eschbach C, Martens U, Hotko Y, Kortsik C, Celik I, Stroh C, Pirker R: Molecular and clinical predictors of outcome for cetuximab in non-small cell lung cancer (NSCLC): Data from the FLEX study. Journal of Thoracic Oncology 2009, 27:15s. (suppl; abstr 8007)

12. Ciardiello F, Tortora G: EGFR antagonists in cancer treatment. N Engl J Med 2008, 358:1160-1174.

13. Fan Z, Masui H, Altas I, Mendelsohn J: Blockade of epidermal growth factor receptor function by bivalent and monovalent fragments of 225 anti-epidermal growth factor receptor monoclonal antibodies. Cancer Res 1993, 53:4322-4328.

14. Kimura H, Sakai K, Arao T, Shimoyama T, Tamura T, Nishio K: Antibodydependent cellular cytotoxicity of cetuximab against tumor cells with wild-type or mutant epidermal growth factor receptor. Cancer Sci 2007, 98:1275-1280

15. Kurai J, Chikumi H, Hashimoto K, Yamaguchi K, Yamasaki A, Sako T, Touge H, Makino H, Takata M, Miyata M, Nakamoto M, Burioka N, Shimizu E: Antibody-dependent cellular cytotoxicity mediated by cetuximab against lung cancer cell lines. Clin Cancer Res 2007, 13:1552-1561.

16. Roda JM, Joshi T, Butchar JP, McAlees JW, Lehman A, Tridandapani S, Carson WE: The activation of natural killer cell effector functions by cetuximab-coated, epidermal growth factor receptor positive tumor cells is enhanced by cytokines. Clin Cancer Res 2007, 13:6419-6428.

17. Dechant M, Weisner W, Berger S, Peipp M, Beyer T, Schneider-Merck T, Lammerts van Bueren JJ, Bleeker WK, Parren PW, van de Winkel JG, Valerius T: Complement-dependent tumor cell lysis triggered by combinations of epidermal growth factor receptor antibodies. Cancer Res 2008, 68:4998-5003.

18. Ajona D, Castano Z, Garayoa M, Zudaire E, Pajares MJ, Martinez A, Cuttitta $\mathrm{F}$, Montuenga LM, Pio R: Expression of complement factor $\mathrm{H}$ by lung cancer cells: effects on the activation of the alternative pathway of complement. Cancer Res 2004, 64:6310-6318.

19. Cragg MS, Howatt WJ, Bloodworth L, Anderson VA, Morgan BP, Glennie $\mathrm{MJ}$ : Complement mediated cell death is associated with DNA fragmentation. Cell Death Differ 2000, 7:48-58.

20. Nicoletti I, Migliorati G, Pagliacci MC, Grignani F, Riccardi C: A rapid and simple method for measuring thymocyte apoptosis by propidium iodide staining and flow cytometry. J Immunol Methods 1991, 139:271-279.

21. Ajona D, Hsu YF, Corrales L, Montuenga LM, Pio R: Down-regulation of human complement factor $\mathrm{H}$ sensitizes non-small cell lung cancer cells to complement attack and reduces in vivo tumor growth. $\mathrm{J} / \mathrm{mmunol}$ 2007, 178:5991-5998.

22. Liszewski MK, Atkinson JP: The complement system. In Fundamental Immunology Third edition. Edited by: Paul WE. New York: Raven Press; 1993:917-939.

23. Mukohara T, Engelman JA, Hanna NH, Yeap BY, Kobayashi S, Lindeman N, Halmos B, Pearlberg J, Tsuchihashi Z, Cantley LC, Tenen DG, Johnson BE, Jänne PA: Differential effects of gefitinib and cetuximab on non-smallcell lung cancers bearing epidermal growth factor receptor mutations. J Natl Cancer Inst 2005, 97:1 185-1194.

24. Steiner P, Joynes C, Bassi R, Wang S, Tonra JR, Hadari YR, Hicklin DJ: Tumor growth inhibition with cetuximab and chemotherapy in non-small cell lung cancer xenografts expressing wild-type and mutated epidermal growth factor receptor. Clin Cancer Res 2007, 13:1540-1551.

25. Glennie MJ, French RR, Cragg MS, Taylor RP: Mechanisms of killing by anti-CD20 monoclonal antibodies. Mol Immunol 2007, 44:3823-3837.

26. Liu J, Gunn L, Hansen R, Yan J: Combined yeast-derived beta-glucan with anti-tumor monoclonal antibody for cancer immunotherapy. Exp Mol Pathol 2009, 86:208-214

27. Natsume A, In M, Takamura H, Nakagawa T, Shimizu Y, Kitajima K, Wakitani M, Ohta S, Satoh M, Shitara K, Niwa R: Engineered antibodies of IgG1/ IgG3 mixed isotype with enhanced cytotoxic activities. Cancer Res 2008, 68:3863-3872

28. Gridelli C, Maione P, Ferrara ML, Rossi A: Cetuximab and other antiepidermal growth factor receptor monoclonal antibodies in the treatment of non-small cell lung cancer. Oncologist 2009, 14:601-611.
29. Siena S, Sartore-Bianchi A, Di Nicolantonio F, Balfour J, Bardelli A: Biomarkers predicting clinical outcome of epidermal growth factor receptor-targeted therapy in metastatic colorectal cancer. $\mathrm{J}$ Natl Cancer Inst 2009, 101:1308-1324.

doi: 10.1186/1476-4598-9-139

Cite this article as: Hsu et al., Complement activation mediates cetuximab inhibition of non-small cell lung cancer tumor growth in vivo Molecular Cancer 2010, 9:139

\section{Submit your next manuscript to BioMed Central and take full advantage of:}

- Convenient online submission

- Thorough peer review

- No space constraints or color figure charges

- Immediate publication on acceptance

- Inclusion in PubMed, CAS, Scopus and Google Scholar

- Research which is freely available for redistribution 